UDC 577.214.6

\title{
Expression of isgylation related genes in regenerating rat liver
}

\author{
A. V. Kuklin'1, T. A. Poliezhaieva², I. O. Zhyryakova ${ }^{2}$, V. V. Ogryzko ${ }^{3}$, \\ M. Yu. Obolenskaya ${ }^{1}$ \\ ${ }^{1}$ Institute of Molecular Biology and Genetics, NAS of Ukraine \\ 150, Akademika Zabolotnoho Str., Kyiv, Ukraine, 03680; \\ ${ }^{2}$ Educational and Scientific Center "Institute of Biology" \\ Taras Shevchenko National University of Kyiv \\ 64/13, Volodymyrska Str., Kyiv, Ukraine, 01601; \\ ${ }^{3}$ CNRS UMR 8126, Universit Paris-Sud 11, Institut Gustave Roussy \\ 114, rue Edouard Vaillant, Villejuif, France, 94805 \\ m.obolenska@gmail.com
}

\begin{abstract}
Our recent studies have revealed the early up-regulated expression of interferon alpha (IFN $\alpha$ ) in the liver, induced by partial hepatectomy. The role of this cytokine of innate immune response in liver regeneration is still controversial. Aim. To analyze expression of canonical interferon-stimulated genes Ube1l, Ube2l6, Trim 25, Usp18 and Isg15 during the liver transition from quiescence to proliferation induced by partial hepatectomy, and acute phase response induced by laparotomy. These genes are responsible for posttranslational modification of proteins by ISGylation. The expression of genes encoding TATA binding protein (TBP) and 18S rRNA served as indirect general markers of transcriptional and translational activities. Methods. The abundance of investigated RNAs was assessed in total liver RNA by real time RT-qPCR. Results. Partial hepatecomy induced steady upregulation of the $T b p$ and $18 S r R N A$ genes expression during 12 hours post-surgery and downregulation or no change in expression of ISGylation-related genes during the first 3 hours followed by slight upregulation at 12 hours. The level of Isg 15 transcripts was permanently below that of the control during the prereplicative period. Laparotomy induced a continuous downregulation of Tbp and $18 S \mathrm{SRNA}$ expression and early (1-3h) upregulation of ISGylation-related transcripts followed by a sharp drop at 6 hours and slight increase/decrease at 12 hours. The changes in the abundance of Ifn $\alpha$ and ISGylation-related mRNAs were oppositely directed at each stage of the response to partial hepatectomy and laparotomy. Conclusion. We suggest that the expression of ISGylation-related genes does not depend on the expression of Ifn $\alpha$ gene after both surgeries. The indirect indices of transcription and translation as well as the expression of ISGylation-relaled genes are principally different in response to partial hepatectomy and laparotomy and argue for the high specificity of innate immune response.
\end{abstract}

Ke y w or d s: Interferon $\alpha$, ISGylation, liver regeneration, acute phase response

\section{Introduction}

Extensive damage of liver parenchyma induced by partial hepatectomy causes an innate immune response manifested by complement activation, cytokine production, expansion of natural killer cells [1-10], activated signaling from several toll-like receptors, and inhibitory signaling from signal trans- ducer and activator factor (STAT) 3 preventing liver failure [11]. These processes direct quiescent liver cells to partially synchronized proliferation with eventual restoration of liver mass and function $[3,4$, 12-14].

One of the active players in innate immunity is interferon $\alpha(\mathrm{IFN} \alpha)$. Its expression is upregulated during the early hours following partial hepatectomy

(C) 2015 A. V. Kuklin et al;; Published by the Institute of Molecular Biology and Genetics, NAS of Ukraine on behalf of Biopolymers and Cell. This is an Open Access article distributed under the terms of the Creative Commons Attribution License (http://creativecommons.org/licenses/by/4.0/), which permits unrestricted reuse, distribution, and reproduction in any medium, provided the original work is properly cited 
in concert with specific intracellular signaling and typical target gene encoding e.g. protein kinase $\mathrm{R}$ [15-18]. The potential role of IFN $\alpha$ in liver restoration is still contentious $[19,20]$.

The present research is focused on the question whether, and in what manner, IFN $\alpha$ impacts the process of liver restoration. IFN $\alpha$ exerts its functions via regulation of gene expression predominantly at the transcriptional level through several pathways, among which the JAK-STAT is a primary signal transduction pathway. Binding of IFN $\alpha$ to its cognate receptors results in the activation of ISGF3 transcription factor (interferon stimulated gene factor 3 ) which specifically binds interferon-stimulated response element (ISRE) in large collection of genes [21].

In this study we address the expression of typical target genes of IFN $\alpha$ that are engaged in the process of ISGylation, a post-translational modification of proteins via transient attachment of small tag protein, a product of interferon stimulated gene 15 (ISG15) $[22,23]$. ISG15, a $17 \mathrm{kDa}$ member of the ubiquitinlike protein group, shows significant sequence homology with ubiquitin (Ub). The mechanism of ISGylation resembles that of ubiquitination and both modifications go through three sequential reactions operated by: activation, or E1 enzyme first forming an ATP-dependent Ub/ISG15-adenylate; conjugation, or E2 enzymes that transfer activated Ub/ISG15 to their active site cysteine; E3 ligases which transfer $\mathrm{Ub} / \mathrm{ISG} 15$ from E2 to target protein forming isopeptide bond between, in most cases, carboxyl group of terminal glycine and $e$-amino groups of lysine residues of target proteins. Protein modification by ISG15 is a reversible process [22-24].

For ISGylation, only one specific E1-like ubiquitin - activating enzyme (Ube1) and three nonspecific E2 enzymes, Ube2L6 (aka UbcH8), Ube2E1 (aka UbcH6) and Ube2E2, are known. Unlike Ube1, the conjugating enzymes may also bind $\mathrm{Ub}$, meaning both ISG15 and Ub conjugating pathways converge at the level of E2 enzyme [25-27]. However, the affinity of Ube2L6 with ISG15-UBE1L is much greater than the affinity with Ub-E1 and the amount of the thioester intermediate formed by Ube2E1 is signifi- cantly lower than that which is formed by Ube2L6. Thus, Ube2L6 is considered as a major E2 enzyme for ISG15 [28]. E3 ligase activities, which provide substrate specificity for the entire process of ISGylation, at the present moment, are represented in rats only by TRIM25 [29]. The deISGylation enzyme isopeptidase Usp18 (aka Ubp43) preferentially removes ISG15 from its conjugates [30].

To get insight into the potential role of IFN $\alpha$ and posttranslational modifications by ISG15 in liver restoration we evaluate the abundance of Ifn $\alpha$ and Isg15 mRNAs along with mRNAs encoding Ube1L, Ube2L6, Trim25 and Usp 18 enzymes in the liver after partial hepatectomy and laparotomy. The abundance of mRNAs encoding TATA-binding proteins (Tbp) and 18S RNA serves as indirect, general markers of transcriptional and translational processes.

\section{Materials and Methods}

\section{Surgical Procedures}

Male Wistar rats (200-250g) were used in the study. Operations of partial hepatectomy and laparotomy were performed according to the standard procedures under ether anesthesia [31]. Three animals were used for each post-surgery time after partial hepatectomy and laparotomy, 24 animals in total. Two resected liver lobes were used as individual controls for the remnant lobes investigated at specific times after partial hepatectomy and as integrated control samples for the liver after laparotomy. After time intervals of $1,3,6$, and 12 hours following partial hepatectomy and laparotomy, the liver was in situ perfused with ice-cold physiological solution, removed and stored at $-80{ }^{\circ} \mathrm{C}$ until use. The Ukrainian law "On the Protection of Animals from Cruelty" was strictly implemented.

\section{$R N A$ isolation}

The total RNA was isolated from approximately $100 \mathrm{mg}$ of liver tissue that was ground in liquid nitrogen with mortar and pestle. Homemade TRIzol (for receipt see Supplement), $1.0 \mathrm{ml}$, was added and the mixture was passed through $22 \mathrm{G}$ needle five 
times. All sequential procedures followed the protocol for RNA isolation with TRIzol ${ }^{\circledR}$ Reagent from manufacturer. The isolated RNA was dissolved in sterile DEPC-treated water, aliquoted and stored at $80{ }^{\circ} \mathrm{C}$. Before the reverse transcription, RNA was subjected to DNAse treatment according to the standard procedure [32] and its concentration was measured on a NanoDrop ND-2000 device (Thermo Scietific, USA). The purity of RNA was assessed by the standard OD ratios (A260/A280 and A260/A230 ranging from 1.8-2.2) and its integrity was assessed according to the $28 \mathrm{~S} / 18 \mathrm{~S}$ ribosomal RNA ratio $(\sim 2.0)$ determined by denaturing formaldehyde agarose electrophoresis. The DNA contamination was controlled via qPCR with primers to $18 \mathrm{~S}$ rDNA without preceding cDNA synthesis. PCR products were visualized in $2 \%$ agarose gel electrophoresis.

\section{Synthesis of RNA Spike}

To absolutely quantify the abundance of investigated RNAs and to maximally diminish the role of potential variability of all procedures preceding $\mathrm{qPCR}$, the exogenous RNA spike was synthesized. For this purpose, the fragment of firefly luciferase gene $(L u c)$, irrelevant to the rat genome, was cut out from the pGL3Basic plasmid (Promega, USA) by XbaI and HindIII restrictases and cloned into the same restriction sites of the pGEM-3Z vector (Promega, USA) according to routine procedures. The obtained product was referred to as pGEM-3ZLuc and was subjected to in vitro transcription. The final mix of $100 \mu \mathrm{l}$ contained $1 \mu \mathrm{g}$ of linearized by EcoRI pGEM-3ZLuc DNA, 2 mM NTP, $10 \mu \mathrm{l}$ of 10x IVT Buffer, $50 \mathrm{U}$ of RiboLock ${ }^{\mathrm{TM}}$ RNAse inhibitor, $30 \mathrm{U}$ of SP6 polymerase (Thermo Scientific, USA). The reaction lasted for 2 hours at $37^{\circ} \mathrm{C}$ and was followed by subsequent phenol/chlorophorm extraction of RNA and ethanol - $0.3 \mathrm{M} \mathrm{NaAc}$ precipitation. The integrity of spike RNA was confirmed by electrophoresis in $1 \%$ agarose gel.

\section{Reverse transcription}

First-strand cDNA synthesis was performed in a total volume of $20 \mu \mathrm{l}$ containing $5 \mu \mathrm{g}$ of total RNA, 10 pg of spike RNA Luc, 100 pmol of random hexamer primers, $20 \mathrm{U}$ of RiboLock ${ }^{\mathrm{TM}}$ RNase inhibitor, $1 \mathrm{mM}$ dNTP mix, $10 \mathrm{mM}$ each and $200 \mathrm{U}$ of MMuLV reverse transcriptase. Random primers, RNAse inhibitor and reverse transcriptase were obtained from Thermo Fisher Scientific, USA. After inactivation of the enzyme by heating for $10 \mathrm{~min}$ at $70{ }^{\circ} \mathrm{C}$ the reaction mix was diluted with sterile DEPC-treated water to the concentration $33 \mathrm{ng} / \mu \mathrm{l}$, aliquoted and stored at $-80^{\circ} \mathrm{C}$.

\section{The qPCR with SYBR green I}

The primers for qPCR were designed with Vector NTI AdvanceTM 9.0 and their specificity was checked with Primer-BLAST program (http://www. ncbi.nlm.nih.gov/tools/primer-blast/). The primers were produced by SyntolTM (Russia, Moscow) and at the IMBG (Kyiv, Ukraine) (Table 1). For the absolute quantitation of mRNA abundance the amplicons for each type of transcript were obtained. The PCR reaction, in total volume of $50 \mu \mathrm{l}$, contained $120 \mathrm{ng}$ of cDNA in $4 \mu 1,20$ pmoles of each primer, $160 \mathrm{nM}$ dNTP, 2 mM MgCl2, 2.5 U Hot Start Taq polymerase (Syntol, Russia) and 5.0 $\mu$ 10x Buffer (Syntol, Russia). Amplification was performed by a 2- step PCR and consisted of an initial denaturation at $94{ }^{\circ} \mathrm{C}$ for $5 \mathrm{~min}$, followed by 35 cycles with denaturation at $94{ }^{\circ} \mathrm{C}$ for $15 \mathrm{sec}$, annealing with simultaneous elongation at $60{ }^{\circ} \mathrm{C}$ for $30 \mathrm{sec}$, and final elongation at 72 ${ }^{\circ} \mathrm{C}$ for $4 \mathrm{~min}$. Amplicons were purified by a Genejet Purification kit (ThermoScientific, USA). The identity of amplicons was controlled by restriction analysis (Table 1). The dilutions of amplicons for the standard curves covered the range of 0.001-10.0 amoles per $25 \mu \mathrm{l}$ of PCR reaction volume.

The estimation of individual RNA abundance was performed in triplicate with PCR in real time on a Bio-Rad CFX96 Real-Time PCR Detection System (Bio-Rad Laboratories Ltd., USA). The $25 \mu$ of PCR mixture contained $66 \mathrm{ng}$ of cDNA, 10 pmoles of each primer, $160 \mathrm{nM}$ dNTP, $2 \mathrm{mM} \mathrm{MgCl} 2,1.25 \mathrm{U}$ of Hot Start Taq polymerase (Syntol, Russia) and $2.5 \mu \mathrm{l}$ of 10x Buffer (50 mM KCl, Tris- $\mathrm{HCl} \mathrm{pH} 8,8)$ with SYBR Green I (Syntol, Russia). To reduce the dimerization of primers for Isg15 amplification $5 \mu$ of $5 \mathrm{x}$ Q-Solution (QIAGEN Inc., Valencia, USA) were 
A. V. Kuklin, T. A. Poliezhaieva, I. O. Zhyryakova et al.

Table 1. Characteristics of primers

\begin{tabular}{|c|c|c|c|c|}
\hline \multirow{2}{*}{$\begin{array}{c}\text { mRNA } \\
\text { (Refseq) }\end{array}$} & \multirow[t]{2}{*}{ Primers } & \multirow{2}{*}{$\begin{array}{l}\text { Amplicon } \\
\text { location, bp }\end{array}$} & \multicolumn{2}{|c|}{$\begin{array}{l}\text { Restriction analysis of } \\
\text { amplicon }\end{array}$} \\
\hline & & & Enzyme & Restricts, bp \\
\hline $\begin{array}{l}\text { Tbp } \\
(\mathrm{NM} \text { _001004198.1) }\end{array}$ & $\begin{array}{l}\text { F 5'- TCAGTCCAATGATGCCTTACG - 3' } \\
\text { R 5'- CTGCTGCTGCTGTCTTTGTT - 3' }\end{array}$ & $348-448$ & Нру 1881 & $50 ; 51$ \\
\hline $\begin{array}{l}18 S \\
\left(\mathrm{NR} \_046237.1\right)\end{array}$ & $\begin{array}{l}\text { F 5'- GTTCCGACCATAAACGATGC-3' } \\
\text { R5'- CGCTCCACCAACTAAGAACG -3', }\end{array}$ & $1078-1341$ & Hinfl & $175 ; 67 ; 44$ \\
\hline Ifno* & $\begin{array}{l}\text { F 5' - CTGCTGTCTAGGATGTGACCTGC -3' } \\
\text { R 5' - TTGAGCCTTCTGGATCTGCTG - 3' }\end{array}$ & $57-225$ & HinfI & $81 ; 46 ; 42$ \\
\hline $\begin{array}{l}\text { Isg15 } \\
(\mathrm{NM} 001106700.1)\end{array}$ & $\begin{array}{l}\text { F 5' - CCTCTGAGCATCCTGGTGAG- 3' R5' - } \\
\text { CAGTGGCTCTTT GTCCTCCA - 3' }\end{array}$ & $376-546$ & PvuII & $58 ; 113$ \\
\hline $\begin{array}{l}\text { Ubell } \\
(\mathrm{NM} \text { _001106856) }\end{array}$ & $\begin{array}{l}\text { F 5' - GGGCCTGGGAGTTAGGGATAATGG- 3', } \\
\text { R 5' - CGTCCACCCTGGAGAAGAAGTCGT - 3', }\end{array}$ & $1492-1730$ & Ear I & $90 ; 149$ \\
\hline $\begin{array}{l}\text { Ube2L6 } \\
\text { (NM_001024755.1) }\end{array}$ & $\begin{array}{l}\text { F 5' -ACCAACTTCCCTATCGCCTCAAGG- 3' } \\
\text { R 5' - GAGGTCAGCTAGTTCCAAACGCACA- 3' }\end{array}$ & $591-850$ & Bgl II & $95 ; 165$ \\
\hline $\begin{array}{l}\text { Trim25 } \\
(\text { NM_001009536.1) }\end{array}$ & $\begin{array}{l}\text { F 5' - CGCAAATGTTCCAGGCACAACC- 3', } \\
\text { R 5' -CATCCTCCAGTGCTTTGCTCGCT - 3' }\end{array}$ & $521-725$ & Rsal & $10 ; 195$ \\
\hline $\begin{array}{l}\text { Usp18 } \\
(\mathrm{NM} 001014058.1)\end{array}$ & $\begin{array}{l}\text { F 5' - ATACAACGTGC CATTGTTTGTCC- 3' } \\
\text { R 5' - TCGGTCCAGATTGT GAACAGATC- 3' }\end{array}$ & $496-627$ & EarI & $48 ; 84$ \\
\hline $\begin{array}{l}\text { Luc ( In vitro transcript } \\
\text { from PGEM-3z-Luc) }\end{array}$ & $\begin{array}{l}\text { F 5' - AACCCTATTCTCCTTCTTCG - 3', } \\
\text { R 5'- ATATCCTTGCCTGATACCTG - 3' }\end{array}$ & $867-1020$ & & \\
\hline
\end{tabular}

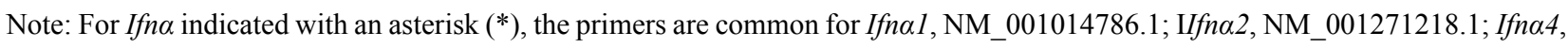
NM_001106667.1 and Ifna16l, XM_575856.1.

added to the mix. On each plate there were the samples from either partial hepatectomy or laparotomy together with the set of corresponding diluted amplicons for standard curve and 'No Template' controls. For the amplification profile, see above. After the PCR procedure, the melting of amplicon was performed with increments of $0.5^{\circ} \mathrm{C}$ over a temperature range of $50{ }^{\circ} \mathrm{C}-95^{\circ} \mathrm{C}$ with an incubation interval of $5 \mathrm{sec}$ at each step. Results of RT-qPCR were processed with a $C F X$ Manager ${ }^{\mathrm{TM}}$ program software (Bio-Rad, USA) using the formula

$$
\log \mathrm{A}_{0}=\left(\mathrm{C}_{\mathrm{q}}-\mathrm{Y}\right) / \mathrm{S} \text {, }
$$

where: $\log \mathrm{A}_{0}-\operatorname{logarithm}$ of the initial amount of mRNA of interest, $\mathrm{C}_{\mathrm{q}}$ - quantification cycle, $\mathrm{Y}-$ the value at the intersection of standard curve with $\mathrm{Y}$ axis, $\mathrm{S}$ - the slope of standard curve. For the example of standard curve see Fig. S1. The units of the calculated amount are the same as the units used to construct the standard curve, the attomoles per the volume of PCR reaction in our case. We transferred the obtained units to copies of target using Avogadro constant.
The data were normalized according to Luc recovery, acquired at no less than $85 \%$. The $100 \%$ value corresponds to the copies of amplified Luc spike per $s e$. The results are represented in the absolute amount of RNA copies per $1 \mathrm{ng}$ of total RNA and in the ratio of abundance at definite postsurgery time to control abundance (fold change), as Mean \pm SEM.

\section{Results and Discussion}

In this work we investigated the abundance of mRNAs, encoding the tag-protein ISG15 and the enzymes responsible for its transient protein attachment and detachment in the scope of general indirect characteristics of transcriptional and translational processes. The intact rat liver, the regenerating liver after $2 / 3$ partial hepatectomy, and the liver after laparotomy were used in the experiment. The first 12 hours post-surgery correspond to the transition and prereplicative periods in the regeneration of the liver and include the liver specific, proliferation-independent acute phase response following laparotomy $[3,4,33,34]$. The acute phase 
response is initiated at the site of trauma, in this case in the areas of the laparotomy and hepatectomy, and acquires the systemic character of the location. The liver supplies the necessary components to confine local tissue destruction, clear the site of harmful agents, and aid the tissue repair $[35,36]$. An acute phase response is thus an intrinsic component of the response to liver injury induced by partial hepatectomy and to laparotomy. The rate of involvement of both types of the aforementioned reactions is under strict regulation subjected to the existing requirements of the organism.

Abundance varies quite significantly within the set of investigated RNAs in the intact liver. 18S RNA is most numerous whereas other RNAs of interest, Usp18, Trim25, Isg15, UbeH8, Tbp, UbelL and Ifn $\alpha$, are present within the intact liver in descending magnitude with respect to the order of the present list (Table 2).

\section{The abundance of Tbp mRNA and $18 S$ rRNA indirectly affects the rate of transcription and translation}

TBP (TATA-binding protein), together with RNA polymerase II and general transcription factors, forms a pre-initiation complex following the reaction with the TATA box in the core promoter. A timedependent profile of $T b p$ mRNA after partial hepa-

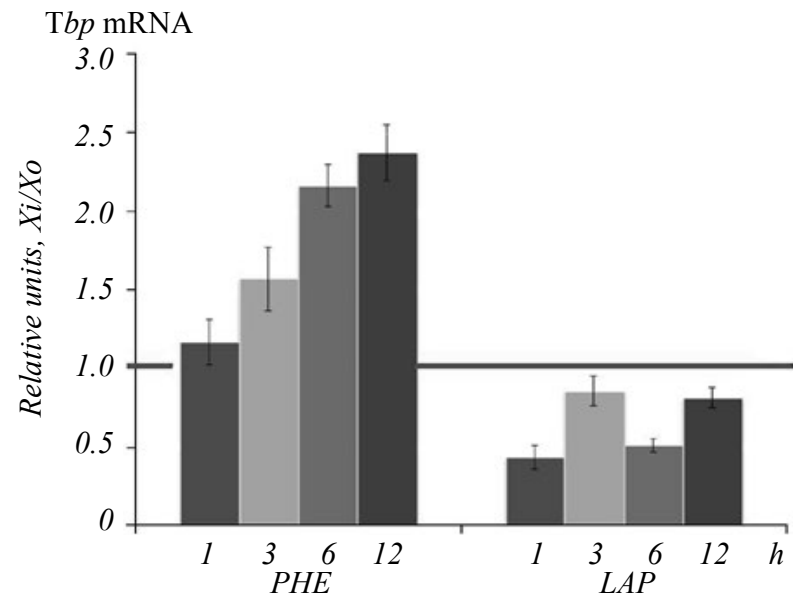

Table 2. Abundance of individual RNAs in total RNA from intact liver

\begin{tabular}{|l|l|}
\hline \multicolumn{1}{|c|}{ Type of RNA } & \multicolumn{1}{c|}{$\begin{array}{c}\text { Copies/ng of total RNA, } \\
\text { Mean } \pm \text { SEM }\end{array}$} \\
\hline Tbp & $443.2 \pm 41.20$ \\
I8S & $2023399.7 \pm 153101.78$ \\
Ifnc & $19.7 \pm 3.29$ \\
Isg15 & $1493.0 \pm 330.12$ \\
Ube1L & $212.8 \pm 27.50$ \\
Ube2L6 & $1107.4 \pm 117,15$ \\
Trim25 & $2190.0 \pm 166.9$ \\
Usp18 & $2670.8 \pm 538.13$ \\
\hline
\end{tabular}

tectomy reveals steady upregulation, while, following laparotomy, it is continuously downregulated (Fig. 1; Table S1). The TATA box is present in approximately $20-30 \%$ of protein-encoding genes, particularly present in genes responsible for stress and inflammation, nucleosome and chromatin assembly, and cell proliferation and development [3740]. So the activated and restricted transcription of corresponding genes by increased and decreased concentration of TBP may be expected after partial hepatectomy and laparotomy, respectively.

$18 \mathrm{~S}$ rRNA is a component of small ribosomal subunits and changes in the amount of cellular rRNA are associated with variation in the rate of ribosome accumulation. The profiles of $18 \mathrm{~S}$ rRNA after both of

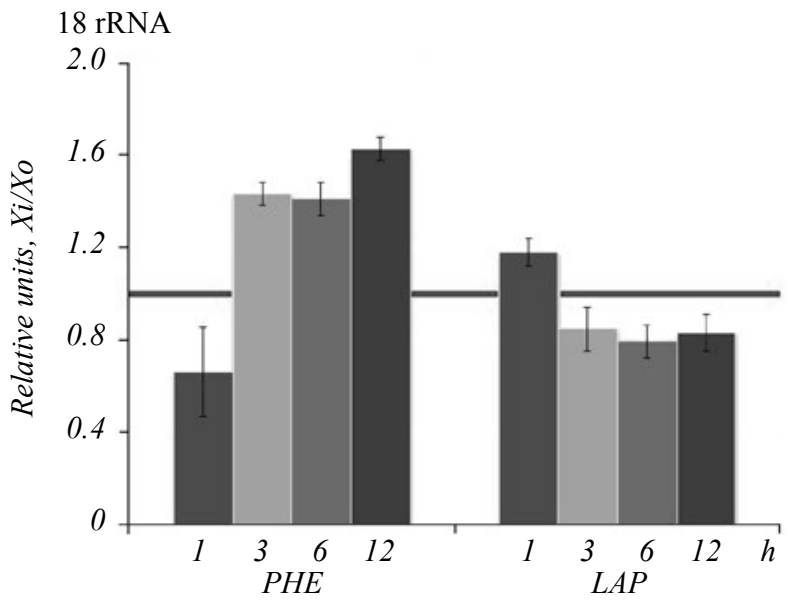

Fig.1. Abundance of Tbp mRNA and $18 S$ RNA in total liver RNA after partial hepatectomy (PHE) and after laparatomy (LAP) Note: $x_{i}$ and $x_{0}$ are the values of mRNA and rRNA abundances in the liver at the indicated post-surgery time and in control liver, correspondingly. The line marks the control level. 

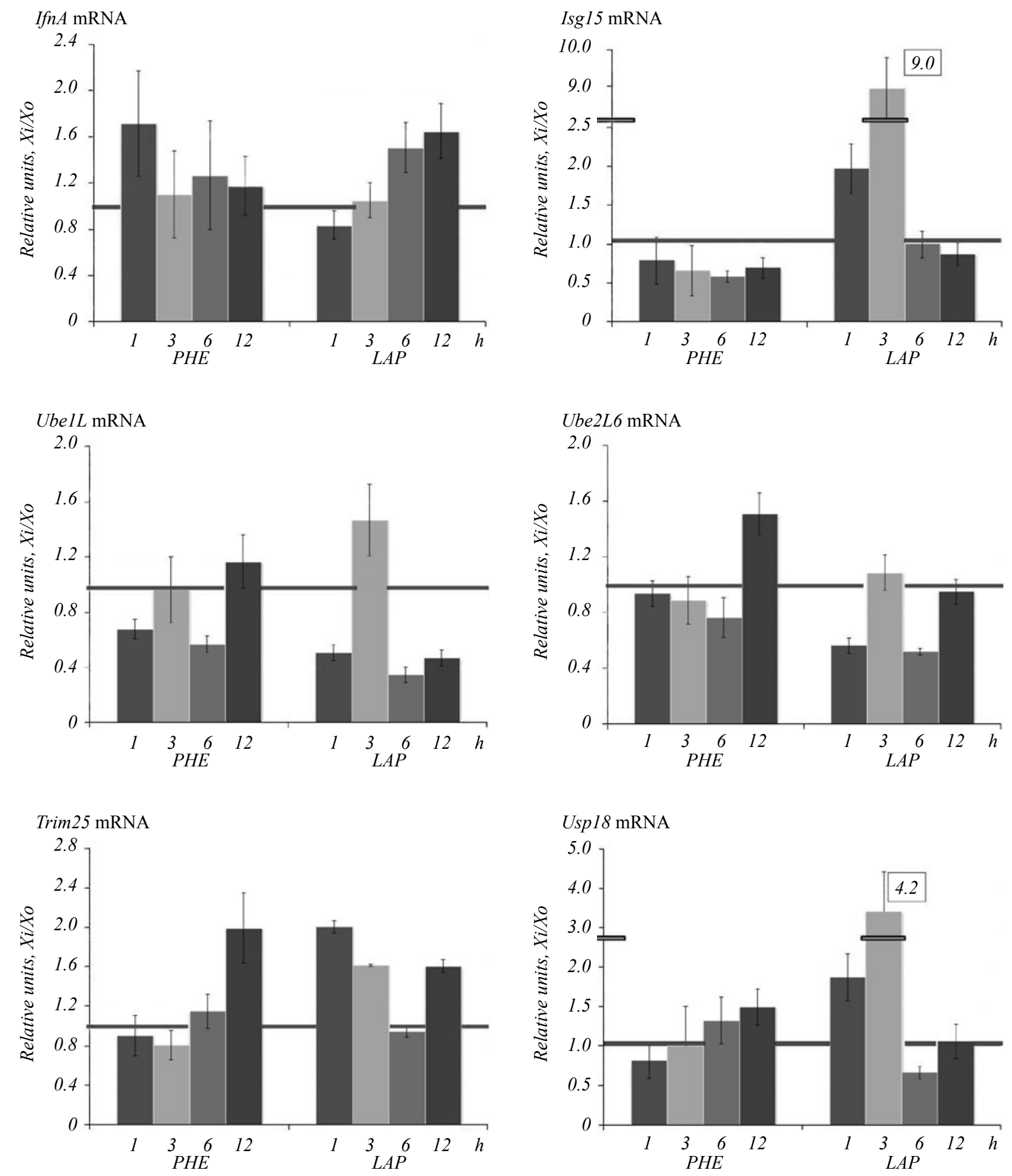

Fig.2. Abundance of individual mRNAs in total liver RNA after partial hepatectomy (PHE) and after laparatomy (LAP). The designation of $x_{i}$ and $x_{0}$ is the same as in Fig.1. 
the surgical procedures studied resemble those of Tbp mRNA discussed above except decrease of its concentration at $1 \mathrm{~h}$ after partial hepatectomy (Fig. 1; Table S1). The gradual upregulation of $18 \mathrm{~S}$ rRNA abundance confirms the well known dynamics of ribosome synthesis during the pre-replicative period of liver regeneration, meeting the vital requirements of the intensive synthesis of the replication machinery components subsequent to the 12 hours postsurgery interval [41-43].

The decrease in Tbp mRNA and $18 S$ rRNA abundance after laparotomy is consistent with the restriction of the synthesis of the so-called negative proteins of the acute phase response (e.g. albumin, transthyretin) for the synthesis of the positive proteins $[35,36]$ and the reduction of translation with its highest energy consumption for a more efficient recovery of homeostasis. After partial hepatectomy the great requirement for energy resources particularly for increased transcription and translation is provided by the profound changes in the liver metabolism while the liver uses the cabohydrates and fatty acids from the muscles and adipose tissue to cover these expenses [44]. So the responses to partial hepatectomy and laparotomy by Tbp mRNA and 18S rRNA abundance are exactly opposite during 12 postsurgery hours.

\section{The abundance of $m R N A$ s is involved in the (de)ISGylation processes}

Liver regeneration is a partially synchronized process that can be observed on a scale of time. The pre-replicative period extends from stimulation to the onset of DNA synthesis and is subdivided in two stages-priming, or promotion, (ca. $3 \mathrm{~h}$ post-surgery) and progression, or the G1 period, corresponding to the first cell cycle of hepatocytes [3, 4, 33, 34]. During the first stage, the liver cells precipitately switch from their "quiescent" program to that committed to the initiation of the cell cycle and cellular preparation for DNA replication, starting ca. $12 \mathrm{~h}$ post-surgery. The marked difference between the abundance of several mRNAs after laparotomy (see below) points also to the existence of specific transition period (1-3 h) during $12 \mathrm{~h}$ response.
The first stage after partial hepatectomy (1-3 h) is characterized by an early transient up-regulation of Ifn $\alpha \mathrm{mRNA}$ and a concomitantly pronounced downregulation of Isg15 and Ube1L mRNAs while the level of other mRNAs remains in the range of control levels or slightly lower (Fig. 2; Table S1). The situation following the laparotomy is significantly different; the early downregulation of Ifn $\alpha$ mRNA abundance coincides with immediate (Isg15, Trim25 and Usp18) upregulated mRNA concentrations; the abundances of Ube1L and Ube2L6 mRNAs are diminished. Despite the variation in the level of mRNAs at $1 \mathrm{~h}$ it is followed by up-regulation at $3 \mathrm{~h}$ especially manifested by $I s g 15$ and Usp $18 \mathrm{mRNAs}$. So a decrease in the protein modification activity may be suggested during the transition period after partial hepatectomy and its activation during the same period after laparotomy.

During the next stage, corresponding to the prereplicative period in hepatocytes induced by partial hepatectomy, the abundance of Ifn $\alpha$ mRNA returns to the initial levels and that of Isg 15 mRNA remains at the low level while the concentrations of all other mRNAs increase slightly during the progression of the 12 hour period. The situation following laparotomy significantly differs yet again. The abundance of Ifn $\alpha$ mRNA increases slightly while the abundance of all other mRNAs drops sharply compared to the concentrations at $3 \mathrm{~h}$ either to control level (Isg15 and Trim25) or even below it (Ube1L, Ube2L6 and Usp 18). At $12 \mathrm{~h}$ post-laparotomy the abundance of mRNAs is either at control level (Isg15, Ube2L6 and Usp 18) or remains below it (Ube1). Only the level of Trim 25 mRNA exceeds control level.

Therefore the changes in the abundance of Ifn $\alpha$ mRNA are oppositely directed with the changes in the abundance of ISGylation-related transcripts at each stage of both processes. As opposed to these data the primary hepatocytes respond to the IFN alpha level recorded after liver resection by upregulation of these ISGylation-related genes expression [45]. The same type of response is recorded during viral infections [21].

The following is noteworthy - many ISGs can be induced by a number of alternate signaling pathways 
activated not only by IFNs [46]. IRF9, a component of transcription factor ISGF3, is a member of the large IFN regulatory factor (IRF) family of proteins, all of which can bind to ISRE or ISRE -like elements. Signaling pathways leading to the induction of ISGs may start at different points but converge at various nodes and all cause the activation of IRF-3 or IRF-7, the transcription factors that are the common denominators of these pathways [46]. The gene ISG15 has the simple promoter driven by ISRE only, and as a result, all agents that can activate transcription factors containing IRF proteins can efficiently induce this gene [46]. So ISGI5 may be used as a pure marker of (in)activating IRF-containing transcription factors.

Unlike the common tendencies in the changes of ISGylation-related transcripts the expression patterns of different genes at each stage of both responses are not completely similar, e.g. the abundance of Isg15 mRNA vs. other mRNAs during 12 hours after partial hepatectomy or Isg 15 and Usp 18 mRNAs vs. other mRNAs during the acute phase response. This differential regulation of IFN response genes suggests that different regulatory pathways and/or involvement of different cell types are operative over time. The mechanisms regulating these distinct expression patterns are not understood, but evidence suggests that the IFN $\alpha / \beta$ response and that of interferon-stimulated genes are certainly complex.

Altogether there is a principle difference in the expression of $T b p, 18 S$ and ISGylation-related genes during transition of quiescent liver cells to the proliferation and highly tissue-specific acute phase response. This fact argues for the high specificity of innate immune response.

The ISGylation-related $m R N A s$, Tbp $m R N A$ and $18 S$ rRNA are differentially involved in liver transition from quiescence to proliferation and acute phase response

IFN $\alpha$ and interferon-stimulated genes products take on a number of diverse roles both enhancing and inhibiting different compounds of innate immunity. Here we addressed the expression of IFN $\alpha$ gene and a number of ISGs coined as ISGylation-related genes, the products of which are engaged in posttranslational modifications of proteins. The expressions of $T b p$ mRNA and $18 S$ rRNA genes were used as the general indirect markers of transcription and translation during the early stages of two pathophysiological settings - liver regeneration and acute phase response.

The various levels of mRNAs encoding the enzymes involved in ISGylation/ ubiquitination can generate profound biological effects. For example, ISGylation of IRF3 increases its stability by preventing polyubiquitination, which leads to sustained transcription factor activity with subsequent activation of ISGs transcription [47]. Similarly, ISGylation of cyclin D1 leads to protein destabilization, reduced activity, and cell cycle inhibition [48]. ISGylation or ubiqitination of 14-3-3s protein in the absence of ISG15, changes its ability to bind a multitude of functionally diverse signaling proteins, including kinases, phosphatases, and transmembrane receptors. Trim 25 may directly downregulate 14-3-3s levels through a proteasome-dependent mechanism and in such way may regulate the cell cycle as $14-3-3$ s is a negative regulator of the cell cycle progression and is important for the G1 and G2 arrest after the DNA damage [49]. 4EHP is an mRNA 5'cap structurebinding protein and acts as a translation suppressor by competing with eIF4E for binding to the cap structure. The ISGylation of 4EHP substantially increases its affinity for binding, thereby enhancing its ability to block the translation initiation [50]. Intracellular ISG15 is a key negative regulator of IFN- $\alpha / \beta$ immunity. It serves not only as a tag protein but ensures the USP18-dependent negative regulation of IFN- $\alpha / \beta$ and prevention of IFN- $\alpha / \beta$-dependent autoinflammation. USP 18 binds to the intracellular domain of IFN $\alpha$ R2, prevents the binding of JAK1, and inhibits IFN signaling [51, 52].

We may speculate that transitorial elevated abundance of ISGylation-related transcripts during the acute phase response may be accompanied by the ISGylation of: 4EHP protein that would support the restricted translation; cyclin $\mathrm{D}$ - to prevent prolifera- 
Expression of isgylation related genes in regenerating rat liver

tion; and by the ISGylation-independetnt activity of USP18 to prevent inflammation. Correspondingly the downregulated expression of ISGylation-related genes during response to partial hepatectomy may be an indispensable prerequisite for production of proinflammatory cytokines (IL-1, TNF alpha, IL-6) that are crucial for progression of regenerating process, and for initiation of replication via G1 check point. The biological effects of posttranslational modification by ISG15 in vivo are still obscure and at the very beginning of their investigation. The new challenges loom in perspective.

\section{Acknowledgment of authors' contributions}

We thank Alex Martiniouk (Yale University, New Haven, USA) for his technical assistance.

This work was supported by the National Academy of Sciences of Ukraine (Project N 2.2.4.18, 20112014, MO, AK and by Ukranian-Indian grant N 2015-2017, MO).

\section{Author Disclosure Statement}

All authors declare that no competing financial interests exist.

\section{REFERENCES}

1. Obolenskaya MYu, Bernauer H, Tran-Thi T-A, Decker K. Levels of RNA for TNF- $\alpha$ and receptors during the prereplicative period of liver regeneration. Biopolym Cell. 1994;10(5):68-77.

2. Decker KF, Obolenskaya MY. Cytokines, nitric oxide synthesis and liver regeneration. J Gastroenterol Hepatol. 1995;10 Suppl 1:S12-7.

3. Obolenskaya MYu. Cytokines and liver regeneration. EOS. 1997; 17(2):51-8.

4. Obolenskaya MYu. Signalling molecules in regenerating liver. Biopolym Cell. 1998;14(3):210-22.

5. Akerman P, Cote P, Yang SQ, McClain C, Nelson S, Bagby GJ, Diehl AM. Antibodies to tumor necrosis factor-alpha inhibit liver regeneration after partial hepatectomy. Am J Physiol. 1992;263(4 Pt 1):G579-85.

6. Cressman DE, Greenbaum LE, DeAngelis RA, Ciliberto $G$, Furth EE, Poli V, Taub R. Liver failure and defective hepatocyte regeneration in interleukin-6-deficient mice. Science. 1996;274(5291):1379-83.

7. Yamada Y, Kirillova I, Peschon JJ, Fausto N. Initiation of liver growth by tumor necrosis factor: deficient liver regen- eration in mice lacking type I tumor necrosis factor receptor. Proc Natl Acad Sci US A. 1997;94(4):1441-6.

8. Fujita J, Marino MW, Wada H, Jungbluth AA, Mackrell PJ, Rivadeneira DE, Stapleton PP, Daly JM. Effect of TNF gene depletion on liver regeneration after partial hepatectomy in mice. Surgery. 2001;129(1):48-54.

9. Markiewski MM, DeAngelis RA, Lambris JD. Liver inflammation and regeneration: two distinct biological phenomena or parallel pathophysiologic processes? Mol Immunol. 2006;43(1-2):45-56.

10. Hosoya S, Ikejima K, Takeda K, Arai K, Ishikawa S, Yamagata H, Aoyama T, Kon K, Yamashina S, Watanabe $S$. Innate immune responses involving natural killer and natural killer $\mathrm{T}$ cells promote liver regeneration after partial hepatectomy in mice. Am J Physiol Gastrointest Liver Physiol. 2013;304(3):G293-9.

11. Iimuro Y, Fujimoto J. TLRs, NF- $\mathrm{BB}, \mathrm{JNK}$, and Liver Regeneration. Gastroenterol Res Pract. 2010;2010. pii: 598109.

12. Michalopoulos $G K$, DeFrances $M$. Liver regeneration. $A d v$ Biochem Eng Biotechnol. 2005;93:101-34.

13. Riehle KJ, Dan YY, Campbell JS, Fausto N. New concepts in liver regeneration. J Gastroenterol Hepatol. 2011;26 Suppl 1:203-12.

14. Fausto N, Campbell JS, Riehle KJ. Liver regeneration. J Hepatol. 2012;57(3):692-4.

15. Perepelyuk MM, Fedorchenko DB, Rybalko SL, Obolenskaya $M Y u$. Interferon $\alpha$ expression in the rat liver after partial hepatectomy. Biopolym Cell. 2006;22(4):276-82.

16. Perepelyuk MM, Kuklin AV, Shcherba IaV, Tokovenko BT, Makogon NV, Gogler A, Szala S, Obolenskaya MYu. Interferon $\alpha$ and protein kinase $\mathrm{R}$ during rat liver restoration after partial hepatectomy. Biopolym Cell. 2009;25(2):145-9.

17. Han $H$, Zhang $L, X u C$. Effects of the pathogen infectionrelated genes on rat liver regeneration following $2 / 3$ hepatectomy. Life Sci J. 2007; 4(2):50-5.

18. Chen $X, X u C$, Zhang $F, M a J$. Microarray approach reveals the relevance of interferon signaling pathways with rat liver restoration post $2 / 3$ hepatectomy at cellular level. J Interferon Cytokine Res. 2010;30(7):525-39.

19. Batusic DS, von Bargen A, Blaschke S, Dudas J, Ramadori $G$. Different physiology of interferon- $\alpha /-\gamma$ in models of liver regeneration in the rat. Histochem Cell Biol. 2011;136(2):131-44.

20. Vaquero J, Riehle KJ, Fausto N, Campbell JS. Liver Regeneration after partial hepatectomy is not impaired in mice with double deficiency of Myd88 and IFNAR genes. Gastroenterol Res Pract. 2011;2011:727403.

21. Sen GC, Sarkar $S N$. The interferon-stimulated genes: targets of direct signaling by interferons, double-stranded RNA, and viruses. Curr Top Microbiol Immunol. 2007;316:233-50.

22. Zhang $D$, Zhang $D E$. Interferon-stimulated gene 15 and the protein ISGylation system. I Interferon Cytokine Res. 2011;31(1):119-30. 
A. V. Kuklin, T. A. Poliezhaieva, I. O. Zhyryakova et al.

23. Jeon YJ, Yoo HM, Chung CH. ISG15 and immune diseases. Biochim Biophys Acta. 2010;1802(5):485-96.

24. Ciechanover $A$. Intracellular protein degradation: from a vague idea thru the lysosome and the ubiquitin-proteasome system and onto human diseases and drug targeting. Cell Death Differ. 2005;12(9):1178-90.

25. Yuan $W$, Krug RM. Influenza B virus NS1 protein inhibits conjugation of the interferon (IFN)-induced ubiquitin-like ISG15 protein. EMBO J. 2001;20(3):362-71.

26. Zhao C, Beaudenon SL, Kelley $M L$, Waddell MB, Yuan W, Schulman BA, Huibregtse JM, Krug RM. The UbcH8 ubiquitin E2 enzyme is also the E2 enzyme for ISG15, an IFNalpha/beta-induced ubiquitin-like protein. Proc Natl Acad Sci U S A. 2004;101(20):7578-82.

27. Takeuchi T, Iwahara S, Saeki Y, Sasajima H, Yokosawa H. Link between the ubiquitin conjugation system and the ISG15 conjugation system: ISG15 conjugation to the UbcH6 ubiquitin E2 enzyme. J Biochem. 2005;138(6):711-9.

28. Durfee LA, Kelley ML, Huibregtse JM. The basis for selective E1-E2 interactions in the ISG15 conjugation system. $J$ Biol Chem. 2008;283(35):23895-902.

29. Inoue S, Urano T, Ogawa S, Saito T, Orimo A, Hosoi T, Ouchi Y, Muramatsu M. Molecular cloning of rat efp: expression and regulation in primary osteoblasts. Biochem Biophys Res Commun. 1999;261(2):412-8.

30. Malakhov MP, Malakhova OA, Kim KI, Ritchie KJ, Zhang $D E$. UBP43 (USP18) specifically removes ISG15 from conjugated proteins. J Biol Chem. 2002;277(12):9976-81.

31. Higgins GM, Anderson RM. Experimental pathology of the liver I. Restoration of the liver of white rat following partial surgical removal. Arch Pathol. 1931; 12:186-202.

32. Rio DC, Ares M Jr, Hannon GJ, Nilsen TW. Removal of DNA from RNA. Cold Spring Harb Protoc. 2010;2010(6):pdb.prot5443.

33. Webber EM, Godowski PJ, Fausto N. In vivo response of hepatocytes to growth factors requires an initial priming stimulus. Hepatology. 1994;19(2):489-97.

34. Fausto N. Liver regeneration. J Hepatol. 2000;32(1 Suppl):19-31.

35. Baumann H, Gauldie J. The acute phase response. Immunol Today. 1994;15(2):74-80.

36. Cray C, Zaias J, Altman NH. Acute phase response in animals: a review. Comp Med. 2009;59(6):517-26.

37. Basehoar AD, Zanton SJ, Pugh BF. Identification and distinct regulation of yeast TATA box-containing genes. Cell. 2004;116(5):699-709.

38. Huisinga KL, Pugh BF. A genome-wide housekeeping role for TFIID and a highly regulated stress-related role for SAGA in Saccharomyces cerevisiae. Mol Cell. 2004;13(4):573-85.

39. Moshonov S, Elfakess $R$, Golan-Mashiach $M$, Sinvani $H$, Dikstein $R$. Links between core promoter and basic gene features influence gene expression. BMC Genomics. 2008;9:92.
40. Han HW, Bae SH, Jung YH, Kim JH, Moon J. Genome-wide characterization of the relationship between essential and TATA-containing genes. FEBS Lett. 2013;587(5):444-51.

41. Obolenskaia MIu, Gerasimova TB, Bilich KM, Platonov $O M$. [Intracellular distribution of newly formed hepatocyte RNA in the 1st hours following partial hepatectomy]. Tsitol Genet. 1987;21(5):376-82.

42. Chaudhuri S, Lieberman I. Control of ribosome syntesis in normal and regenerating liver. J Biol Chem. 1968;243(1):29-33.

43. Dabeva MD, Dudov KP. Transcriptional control of ribosome production in regenerating rat liver. Biochem $J$. 1982;208(1):101-8.

44. Huang J, Rudnick DA. Elucidating the metabolic regulation of liver regeneration. Am J Pathol. 2014;184(2):309-21.

45. Kuklin A, Tokovenko B, Makogon N, Oczko-Wojciechowska $M$, Jarzab B, Obolenskaya M. Hepatocytes response to interferon alpha levels recorded after liver resection. J Interferon Cytokine Res. 2014;34(2):90-9.

46. Sen GC, Sarkar $S N$. The interferon-stimulated genes: targets of direct signaling by interferons, double-stranded RNA, and viruses. Curr Top Microbiol Immunol. 2007;316:233-50.

47. Shi HX, Yang K, Liu X, Liu XY, Wei B, Shan YF, Zhu LH, Wang $C$. Positive regulation of interferon regulatory factor 3 activation by Herc5 via ISG15 modification. Mol Cell Biol. 2010;30(10):2424-36.

48. Feng Q, Sekula D, Guo Y, Liu X, Black CC, Galimberti F, Shah SJ, Sempere LF, Memoli V, Andersen JB, Hassel BA, Dragnev $K$, Dmitrovsky $E$. UBE1L causes lung cancer growth suppression by targeting cyclin D1. Mol Cancer Ther. 2008;7(12):3780-8.

49. Urano T, Saito T, Tsukui T, Fujita M, Hosoi T, Muramatsu M, Ouchi Y, Inoue S. Efp targets 14-3-3 sigma for proteolysis and promotes breast tumour growth. Nature. 2002;417(6891):871-5.

50. Okumura F, Zou $W$, Zhang DE. ISG15 modification of the eIF4E cognate 4EHP enhances cap structure-binding activity of 4EHP. Genes Dev. 2007;21(3):255-60.

51. Zhang X, Bogunovic D, Payelle-Brogard B, Francois-Newton $V$, Speer $S D$, Yuan $C$, et al. Human intracellular ISG15 prevents interferon- $\alpha / \beta$ over-amplification and auto-inflammation. Nature. 2015;517(7532):89-93.

52. Schneider $W M$, Chevillotte $M D$, Rice $C M$. Interferon-stimulated genes: a complex web of host defenses. Annu Rev Immunol. 2014;32:513-45.

\section{Експресія генів, продукти яких задіяні в ІСГілюванні, в печінці щурів, що регенерує}

А. В. Куклін, Т. О. Полєжаєва, І. О. Жирякова, В. В. Огризько, М. Ю. Оболенська

Наші нещодавні дослідження показали, що на ранньому етапі відновлювального процесу активується синтез інтерферону $\alpha$ (IFN $\alpha)$, цитокина вродженого імунітету. Роль IFN $\alpha$ в процесі відновлення печінки поки що не з'ясована. Мета. Проаналізувати 
Expression of isgylation related genes in regenerating rat liver

експресію класичних інтерферон-стимульованих генів (ICГ), Ubell, Ube2l6, Trim25, Usp 18 i Isg15, в печінці під час їі переходу від стану спокою до проліферації у відповідь на часткову гепатектомію й під час реакції гострої фази після лапаротомії. Ці гени відповідають за посттрансляційну модифікацію білків шляхом ІСГілювання. Рівень експресії генів, які кодують $18 \mathrm{~S}$ pРНК і транскрипційний фактор ТВР, що зв'язується з ТАТАбоксом, використали в якості непрямого показника інтенсивності трансляції і транскрипції. Методи. Концентрацію індивідуальних РНК визначали в тотальній РНК печінки методом зворотної транскрипції і ланцюгової полімеризації в реальному часі. Результати. Часткова гепатектомія викликає поступове підвищення експресії генів Tbp i $18 S r R N A$ впродовж 12 год. після операції і зниження експресії генів ІСГілювання впродовж перших трьох годин 3 наступним незначним підвищенням до 12 год. Рівень Isg15 транскриптів залишається зниженим впродовж всього періоду дослідження. Лапаротомія викликає поступове зниження експресії генів $T b p$ і $18 S r R N A$ і виражене підвищення концентрації транскриптів генів ІСГілювання на першому етапі (1-3 год.), що змінюється різким зниженням до 6-ої год. 3 наступним незначним підвищенням/зниженням до 12-ої год. Зміни в рівні транскриптів гена Ifna і генів системи ІСГілювання носять протилежний характер на кожній із стадій відповіді печінки на часткову гепатектомію і лапаротомію. Висновки. Припускаємо, що експресія генів, які задіяні в процесі ІСГілювання, не залежить від експресії гена Ifn $\alpha$. Використані «показники» активності транскрипції, трансляції і посттрансляційної модифікації білків шляхом ІСГілювання принципово відрізняються між двома реакціями відповіді печінки на часткову гепатектомію і лапаротомію, що свідчить про специфічність реакцій вродженого імунітету.

Кл ю ч о в і с л о в а: Інтерферон $\alpha$, ІСГілювання, регенерація печінки, реакція гострої фази

\section{Экспрессия генов, продукты которых участвуют в ИСГилировании, в регенерирующей печени крыс}

\author{
А. В. Куклин, Т. А. Полежаева, И. А. Жирякова, \\ В. В. Огрызько, М. Ю. Оболенская
}

Наши недавние исследования показали, что после частичной гепатэктомии на раннем этапе восстановительного процесса активируется синтез интерферона альфа (IFNa), цитокина в системе врожденного иммунитета. Роль IFN $\alpha$ в процессе регенерации пока не ясна. Цель. Проанализировать экспрессию классических интерферон-стимулируемых генов Ubell, Ube2l6, Trim 25, Usp18 and Isg15 в процессе перехода печени из состояния покоя к пролиферации в ответ на частичную гепатектомию и во время реакции острой фазы после лапаротомии. Эти гены ответственны за посттрансляционную модификацию белков путем ИСГилирования. Уровень экспрессии генов, которые кодируют транскрипционный фактор ТВР и $18 \mathrm{~S}$ рРНК, использовали в качестве непрямого показателя интенсивности транскрипции и трансляции. Методы. Концентрацию исследуемых РНК определяли в тотальной РНК печени методом обратной транскрипции и цепной полимеризации в реальном времени. Результаты. Частичная гепатэктомия вызывает постепенное повышение экспрессии генов $T b p$ и $18 S r R N A$ в течение 12 час после операции и снижение экспрессии генов ИСГилирования в период 1 - 3 ч с последующим незначительным повышением к 12 ч. Уровень Isg15 транскриптов неизменно снижен в течении всего исследуемого периода. Лапаротомия вызывает постепенное снижение экспрессии генов $T b p$ и $18 S$ $r R N A$ и выраженное повышение концентрации транскриптов генов, участвующих в ИСГилировании (1-3 ч), которое сменяется резким снижением к 6 ч и последующим незначительным повышением/снижением к 12 ч. Изменения в уровнях транскриптов Ifn $\alpha$ и транскриптов генов системы ИСГилирования носят разнонаправленный характер на каждой из стадий ответа печени на частичную гепатэктомию и лапаротомию. Выводы. Предполагаем, что экспрессия генов, определяющих ИСГилирование, не зависит от экспрессии гена Ifno. Использованные «показатели» активности процессов транскрипции, трансляции и посттрансляционной модификации белков путем ИСГилирования в ответ на частичную гепатэктомию и лапаротомию принципиально различны и свидетельствуют в пользу специфичности реакций врожденного иммунитета.

Кл ючев ы е сл ов а: Интерферон $\alpha$, ИСГилирование, peгенрация печени, реакция острой фазы

Received 10.06.2015 